\title{
Job Characteristics as the Antecedents of Work-to-family Enrichment: A Literature Review
}

\author{
${ }^{*}$ Siti Khadijah Zainal Badri, Siti Aisyah Panatik \\ Universiti Teknologi Malaysia \\ *skhadijahzbadri89@gmail.com
}

\begin{abstract}
Work-to-family enrichment refers to the work and family interdependency which is beneficial to the human being. It is a positive construct which views the work-family relationship in a positive perspective. Work-to-family enrichment is a situation where the positive experience in work helps to enrich the participation in family domain. Previous literature suggest that job characteristics are among the relevent predictors of work-to-family enrichment. Job Characteristic Model (JCM) is a popular model which explains the impact of work design towards an various psychological state and outcome. JCM consists of five predictive core job dimensions which are skill variety, task identity, task significance, autonomy and feedback.The current paper discusses the role of five core job dimension in JCM as antecedents to the work-to-family enrichment. Specifically, it includes the past literatures which discusses the relationship between the five core job dimensions and work-to-family enrichment. The paper also includes implications of the study to the future researcher.
\end{abstract}

Keywords: Work-to-family Enrichment, Job Characteristic Model (JCM)

\section{Introduction}

Work-family enrichment is a topic which had grabbed much intellectual discussion nowadays. Organization centralization on the positive problem solving approach had changed the focus of workfamily research towards discussing work-family construct in a positive perspective such as work-family enrichment. Work-family enrichment is argued to be a potential reference in redesigning better workfamily policies. In organizational level, it was suggested to be a relevant future guideline in redesigning a better work environment to the employee(Gryzwacz \& Butler, 2005). The construct of work-family enrichment had been defined by Greenhaus and Powell (2006) as the extent to which active individual participation in one role positively affect the another role. Basically, enrichment concept challenged the depletion process where the construct was suggested to initiate enriching effects rather than draining effects (Rothbard, 2001). Previoulsy, work-family enrichment had been linked with various antecedents such as work, family and personal factors (Shaffer,Joplin, \& Hsu, 2011). Practically, work-family enrichment was divided into two sub-domains which are work-to-family and family-to-work. Yet, the work-to-family construct was claimed to be more relevant with the work antecedents(Greenhaus and Powell 2006). It was argued that that the presence of work-to-family enrichment was associated with the existance of good job characteristics in the workplace (Grzywacz \& Butler, 2005).

An online global career organization which is Monster TRACK had reported that majority of nowdays young job seeker started to acknowledge on the role of good job characteristics such as good benefit, job security and work-flexibility towards promoting good workers well-being and work-life balance (Chao \& Gardner, 2007). The ideas of how job characteristics influence the workers are being discussed in a popular job design model namely the Job Characteristic Model by Hackman and Oldham (1980). Job characteristics model (JCM) is a job design model which focuses on investigating the effects of work design in motivational perspectives. The centralization of this model is to specifically explain on how good job characteristics contribute to the experience of positive critical psychological condition which in turn generate positive work/individual outcomes. The JCM model consists of five main core job dimensions which are skill variety, task identity, task significance, autonomy and feedback. The five core job dimensions were argued to be vital indicators in balancing individual needs and motivation in working environment. Previoulsy, it was claimed by Wan Rashid, Nordin, Omar and Ismail (2011) which had stated that workers with virtuous job characteristics will experience higher work-to-family enrichment. Specifically, high social support at work (Karatepe \& Bekteshi, 2008), good work identity ( Wayne, Grzywacz, Carlson, \& Kacmar, 2007), flexible working hour,clear work description (Shaffer et al., 
2011) and moderate level of job demands (Proost, de Witte, de Witte, \& Schreurs, 2010) found to increase the level of work-to-family enrichment. Additionally, high job autonomy and high skill variety was also found to significantly increase the level of work-to-family enrichment (Grzywacz and Butler ,2005 ).

\section{Literature Review}

Work-family enrichment: The intersection of work and family domains had been extensively discussed in the past 30 years (Burke, 1988; Carlson \& Perrewe, 1999; Dugan, Matthews, \& Barnes-Farrell, 2012; Hammer, 2003; Hostetler, Desrochers, Kopko, \& Moen, 2012; Lu, Tjosvold, Shi, \& Wang, 2012; Michel, Kotrba, Mitchelson, Clark, \& Baltes, 2011; Ozbilgin, Beauregard, Tatli, \& Bell, 2011; Seery, Corrigall, \& Harpel, 2008; Voydanoff, 2005). The increasing commitment of dual-earner couple had captured researchers interest to deeply investigate on the balance of work-family interaction (Greenhaus \& Powell, 2006; Grzywacz \& Butler,2005; Rothbard,2001). Previously, most researchers had emphasized on the negative construct of work-family conflict as it was more dominant compared to the positive construct of work-family enrichment (Greenhaus, Parasuraman, Granrose, Rabinowitz, \& Beutell, 1989; Greenhaus \& Beutell, 1985).Yet, in early of $20^{\text {th }}$ century, the focus of work-family research had started to change direction. Researchers had argued that positive constructs of work-family enrichment need to be emphasized (Greenhaus \& Powell, 2006). As stated by Greenhaus and Parasuraman (1999) "few studies have acknowledged the possibility that work and family roles can have positive or enriching effects on one another". Since then researchers started to claim on the existence of the positive direction of work-family relation such as work-family enrichment (Kinnunen, Feldt, Geurts, \& Pulkkinen, 2006; Wayne, Randel, \& Stevens, 2006). The work-family enrichment idea was initially discussed on an article entitled "When Work and Family Are Allies: A Theory of Work-Family Enrichment" (Greenhaus \&Powell, 2006). The article highlighted that the participation in one roles helps to improve participation in another role. The transferring of the positive energy is the central issue in work-family enrichment (Gareis, Barnett, Ertel, \& Berkman, 2009). Explicitly, the positive experience in one role will initiate a positive energy in another role (Marks,1977).

Theoritically,work-family enrichment resembles with two similar concepts namely work-family positive spillover (Edwards \& Rothbard, 2000) and work-family family facilitation (Wayne,Grzywacz, Carlson, \& Kacmar, 2007). These three concepts correspondingly view work-family interaction as a process whereby involvement in one domain brings benefits and improve performance or involvement in another domain (Greenhaus \& Powell, 2006). One of the theories that was best reflected with the work-family enrichment process is a role accumulation theory (Sieber,1974). The theory highlighted that the experience in one role will lead to the positive experience in another role. Empirically, work-family enrichment was found to be highly associated with healthy working and balanced nation (Demerouti, Peeters, \& van der Heijden, 2012). Individual who participates equally in work and family is suggested to experience role enriching process which leads to greater well-being than those who participate only in one role (Swee Fung \& Ahmad, 2012). For instance, individual with high work-family enrichment found to have higher job/family satisfaction, affective commitment and physical/mental health (McNall, Nicklin, \& Masuda, 2010). In this paper, only work-to-family enrichment is discussed with job characteristics. It is because, empirical evidence consistenly showing that work-to-family direction is more related to the work antecedents.

Job characteristics model:Briefly,JCM is composed of four main components which are job characteristics (predictors), critical psychological states (mediator), personal and work outcomes (dependent) and moderator variables (i.e.growth-need strength, knowledge and skill, "context" satisfaction). As stated above, the five job characteristics are proposed to affect the critical psychological states. That is, skill variety, task identity and task significance were proposed to enhance responsibility in work outcomes development. Autonomy was proposed to strengthen the knowledge of the results of the work activities. Meanwhile, feedback was proposed to increase employee's meaningfulness of the work. According to Hackman and Oldham (1980) job characteristics lead to the experience of critical states which affect the job and personal outcome. Moreover, the moderator variables (i.e. growth-need strength, knowledge and skill, "context" satisfaction) were proposed to moderate the relationship between 1) job characteristics and critical psychological states; and 2) critical psychological states and personal/work outcomes. In this study, work-to-family enrichment contends to be a possible consequence of job characteristics since good job characteristics are associated with positive event 
(Hackman \& Oldham,1980).Table 1 below illustrates the past empirical evidence on five core job dimensions with work-to-family enrichment.

Table 1: Literature review on the previous reported finding between job characteristics and workfamily enrichment

\begin{tabular}{|c|c|}
\hline Author (Year) & Variables \\
\hline $\begin{array}{l}\text { Grzywacz and Butler } \\
(2005)\end{array}$ & $\begin{array}{l}\text { Antecedents } \\
\text { - Job characteristics } \\
\text { * Substantive complexity } \\
\text { * Physical and environmental } \\
\text { demands } \\
\text { * Manipulative and social skills } \\
\text { * Social skills } \\
\text { *Authority } \\
\text { *Variety } \\
\text { Outcomes } \\
\text { - Work-family facilitation } \\
\text { - Personal growth }\end{array}$ \\
\hline $\begin{array}{l}\text { Baral \& Bhargava } \\
(2011)\end{array}$ & $\begin{array}{l}\text { Outcomes } \\
\text {-Core self-evaluation } \\
\text { - Family support } \\
\text { - Supervisor support } \\
\text { - Co-employee support } \\
\text { - Job characteristics } \\
\text { - Work-life balance policies } \\
\text { - Work-family culture }\end{array}$ \\
\hline & $\begin{array}{l}\text { Outcomes } \\
\text { - Work-family enrichment }\end{array}$ \\
\hline $\begin{array}{l}\text { Thompson \& Prottas } \\
(2006)\end{array}$ & $\begin{array}{l}\text { Antecedents } \\
\text {-Formal organizational } \\
\text { support }\end{array}$ \\
\hline & $\begin{array}{l}* \text { Family alternatives } \\
{ }^{*} \text { Alternatives schedule }\end{array}$ \\
\hline & $\begin{array}{l}\text {-Informal organizational } \\
\text { support } \\
\text { *Supervisor support } \\
\text { *Co-employee support } \\
\text { - Work-family culture } \\
\text { - Job characteristic } \\
\text { *Job autonomy } \\
\text {-Perceived control (mediator) }\end{array}$ \\
\hline & $\begin{array}{l}\text { Outcomes } \\
\text {-Work-family enrichment } \\
\text {-Work-family conflict } \\
\text {-Family, Life and } \\
\text { Job satisfaction } \\
\text {-Stress and well-being } \\
\text {-Turnover intention }\end{array}$ \\
\hline Siu et al. (2010) & $\begin{array}{l}\text { Antecedents } \\
\text {-Work engagement } \\
\text {-Family-friendly } \\
\text { organizational policies } \\
\text {-Supervisor support } \\
\text {-Colleague support }\end{array}$ \\
\hline
\end{tabular}

Findings related with job characteristics and work-family enrichment

Work arrangement, authority and social skill found to promote high levels of work-to-family enrichment.

Individuals whose job whichis more physically and environmentally demanding were reported to experience lower work-to- family enrichment.

Resources rich job enable employee to have high work-family enrichment.

Positive association was found between job characteristics and work-to-family enrichment. *Note: Job characteristics were generally measured, it not specifically tested.

Good family support, core self-evaluation, worklife balance policies and work-family culture had increased work-to-family enrichment.

Job autonomy was positively associated with work-to-family enrichment.

Support from co-employees and supervisor were positively related with work-to-family enrichment.

Job autonomy was positive significantly related with work-to-family enrichment.

High supervisor support had increased level of work-to-family enrichment. 
-Job autonomy

-Family support

-Work engagement (mediator)

Outcomes

-Work-family enrichment

Beham,Drobnič, Präg (2011)

Hill et al. (2007)

- Psychological job demands

-Job insecurity

-Organizational

expectation

-Flexible working arrangement

-Supervisor support

-Co-employees support

-Job control

-Job variety

Outcomes

Work-family interference

Work-family enrichment

Antecedents
Boundary-spanning resources, supervisor support, co-worker support and flexible work arrangements were significant positively related with work-to-family enrichment.

time

Job variety was significant positively related with work-to-family enrichment.

-Resources and support

*Flexible Work Policies

*Supportive Organizational

Culture

*Supervisor Support

*Work Group Support

*Work-at-Home

* Free Time

*Married

*Stay-at-Home Spouse

-Stressor and demands

*Job Hours

*Job Pressure

${ }^{*}$ Child care

*Hours

*Household Chore Hours

*Preschooler at Home

-Work-family conflict

(mediator/outcome)

-Work-family enrichment

(mediator/outcome)

Outcomes

-Job Satisfaction

-Organizational Commitment

-Family Satisfaction

-Marital Satisfaction

-Life Satisfaction

-Individual Stress

Moderator

-Gender

Karatepe \& Bekteshi Antecedents

(2008)
Job control was not significant with work-tofamily enrichment.

Flexible benefits was positively related work-tofamily enrichment.

Supervisor support (job) was positively related to work-to-family enrichment.

Work group support was positively related to work-to-family enrichment.

Job hours was not significan in predicting workto-family enrichment.

Supportive organizational culture was not significant in predicting work-to-family enrichment.
Work support was positively related with workto-family enrichment. 


$\begin{array}{ll} & \text { Outcomes } \\ & \text {-Work-family enrichment } \\ & \text {-Work-family conflict } \\ \text { Butler,Grzywacz, Bass, } & \text { Antecedents } \\ \text { \& Linney (2005) } & \text {-Daily control } \\ & \text { - Control } \\ & \text {-Skill level } \\ & \\ & \text { Outcomes } \\ & \text {-Work-family enrichment } \\ & \text {-Work-family conflict } \\ & \text { *Parental leave } \\ & \text { *Time off for family } \\ & \text { *Supportive work-family } \\ & \text { culture } \\ \text { *Supervisor } & \text { support work-family } \\ & \end{array}$

Outcomes

-Work-family enrichment
High demands was significantly decreased workto-family enrichment.

High control was significantly increased work-tofamily enrichment.

High skill level was significantly increased the level of work-to-family enrichment.

Autonomy, learning opportunities, respect and meaningful of work were positively related to the work-to-family enrichment.

Work-family organizational support (supportive work-family culture and supervisor work-family support) increased work-to-family enrichment

\section{Source: prepared by author}

Based on the table 1 above, various job characteristics were empirically found to be associated with work-to-family enrichment. It is found that overall, employees who perceived good job characteristics were found to have higher level of work-family enrichment. This had been inline with the argument by Zimmerman and Hammer (2010) which stated that job characteristics play a significant role in initiating work-to-family enrichment. Virtually, the researcher had found that high autonomy and high social support were associated with high work-to-family enrichment. Both of the varibles found to be among the popular job characteristics variables which often discuss with work-to-family enrichment. Specifically, employee with freedom in scheduling their task (high autonomy) will have higher work-to-family enrichment (Thompson \& Prottas, 2006). In addition, high perceived work and social support found to promote to the higher level of work-family enrichment (Kretepe \& Bekteshi, 2008). Butler,Grzywacz, Bass, and Linney (2005) indicated that high skill level was significant in predicting work-to-family enrichment. Additionally, learning opportunities, respect and meaningful of work were positively related with work-to-family enrichment (Voydanoff, 2004). Learning opportunities provide employee with new experience which helps in the development of variety skills. Additionally, respect leads to higher workfamily enrichment since being respected may lead the individual to have positive emotional state.

Future Research Direction: From the literature review, it is found that job autonomy and social support were among popular variables that had been associated with work-to-family enrichment. Meanwhile, in the Job Characteristics Model point of view, it is found that only skill variety and job autonomy which were frequently been tested with work-to-family enrichment. Yet, the effect of other three job characteritics which are task significance, task identity and feedback were less supported. As JCM is among significant work design model (Hackman \& 0ldham, 1980; Panatik, 2010) thus it is essential for all the job characteristics to be equally tested with work-to-family enrichment. It is suggested that the association of the job characteristics specifically task significance, task identity and feedback need to be deeply investigated in order to have a holistic understanding on how the five job core dimensions are linked with work-to-family enrichment. It is believed that the current empirical evidence is still less explained on the linkages between the five core job dimensions of JCM with and work-to-family enrichment. More studies are suggested to be conducted in order to clarify the linkages between the variables. It is also believed that more research need to be done in explaining the work-to-family enrichment in Malaysian context since most studies were dominated by western perspectives. As Malaysia and Western countries shares the different values perhaps the previous finding from Western research does not accurately fit in with Malaysian context. Therefore, the researchers suggested that more research need to be done in confirming the linkages between job characteristics and work-to-family enrichment especially in Malaysian context. 


\section{Conclusion}

In conlusion, job characteristic plays an important role to promote high work-to-family enrichment. Better understanding on work-to-family enrichment and job characteristics can be used as a guideline for the future researcher in explaining the relationship between job characteristics and work-to-family enrichment. In organizational perspectives, superior understanding on the job characteristics and workto-family enrichment may benefit the organization by giving a proper guidelines in buliding better work policy in the future.

\section{References}

Baral, R., Bhargava, S. (2011). Predictors of work-family enrichment: moderating effect of core selfevaluations. Journal of Indian Business Research, 3(4), 220-243.

Beham, B., Drobnič, S. \& Präg, P. (2011). Work demands and resources and the work-family interface: Testing a salience model on German service sector employees. Journal of Vocational Behavior, 78(1), 110-122

Bulter, A. B. , Grzywacz, J. G., Bass, B. L. \& Linney, K. D. (2005). Extending the demands-control model: A daily diary study of job characteristics, work-family conflict and work-family facilitation. Journal of Occupational and Organizational Psychology, 78(2), 155-169

Burke, R. J. (1988). Some antecedents and consequences of work-family conflict. Journal of social behaviour and personality, 3, 287-302.

Carlson, D. S. \& Perrewe, P. L. (1999). The role of social support in the stressor-strain relationship: An examination of Work-family conflict. Journal of Management, 25(4), 515-540.

Chao, G. T. \& Gardner, P. D. (2007). Important Characteristics of Early Career Jobs: What Do Young Adults Want? : Monster TRACK.

Demerouti, E., Peeters, M. C. W. \& van der Heijden, B. I. J. M. (2012). Work-family interface from a life and career stage perspective: The role of demands and resources. International Journal of Psychology, 47(4), 241-258.

Dugan, A. G., Matthews, R. A. \& Barnes-Farrell, J. L. (2012). Understanding the roles of subjective and objective aspects of time in the work-family interface. Community, Work and Family, 15(2), 149172.

Edwards, J. R. \& Rothbard, N. P. (2000). Mechanisms Linking Work and Family: Clarifying the Relationship between Work and Family. The Academy of Management Review, 25, 178-199.

Gareis, K. C., Barnett, R. Ch., Ertel, K. A. \& Berkman, L. F. (2009). Work-Family Enrichment and Conflict: Additive Effects, Buffering, or Balance? Journal of Marriage and Family, 71(3), 696-707.

Greenhaus, J. H. \& Beutell, N. J. (1985). Sources of conflict between work and family roles. Acedemy of Managememnt Review, 10, 76-88.

Greenhaus, J. H. \& Parasuraman, S. (1999). Research on work, family, and gender: Current status and future directions. In G. N. Powell (Ed.), Handbook of gender and work (pp. 391-412). CA: Thousand Oaks: Sage.

Greenhaus, J. H., Parasuraman, S., Granrose, C. S., Rabinowitz, S. R. \& Beutell, N. J. (1989). Sorces of work family conflict among two-career couples. Journal of Vocational Behaviour, 34, 133-135.

Greenhaus, J. H. \& Powell, G. N. (2006). When Work and Family Are Allies: A Theory of Work-Family Enrichment. The Academy of Management Review, 31(1), 72-92.

Grzywacz, J. G. \& Butler, A. B. (2005). The Impact of Job Characteristics on Work-to-Family Facilitation: Testing a Theory and Distinguishing a Construct. Journal of Occupational Health Psychology, 10(2), 97-109.

Grzywacz, J. G. \& Butler, A. B. (2005). The Impact of Job Characteristics on Work-to-Family Facilitation: Testing a Theory and Distinguishing a Construct. Journal of Occupational Health Psychology, 10(2), 97-109. doi: 10.1037/1076-8998.10.2.97

Hackman, J. R., Oldham, G. R. (1980). Work Redesign. Massachusetts: Addison-Wesley

Hammer, L. B. (2003). Work-family facilitation:An expansion of the work-family paradigm- Research perspectives on alcohol and the family. Paper presented at the Symposium conducted at the 18th Annual Society for Industrial and Organizational Psychology Conference, Orlando, FL. 
Hill, J., Allen, S., Jacob, J., Bair, A. F., Bikhazi, S. L., Van Langeveld, A. \& Walker, E. (2007). Work-Family Facilitation: Expanding Theoretical Understanding Through Qualitative Exploration. Advances in Developing Human Resources, 9(4).

Hostetler, A. J., Desrochers, S., Kopko, K. \& Moen, P. (2012). Marital and family satisfaction as a function of work-family demands and community resources: Individual- and couple-level analyses. Journal of Family Issues, 33(3), 316-340.

Karatepe, O. M. \& Bekteshi, L. (2008). Antecedents and outcomes of work-family facilitation and familywork facilitation among frontline hotel employees. International Journal of Hospitality Management, 27(4), 517-528.

Kinnunen, U., Feldt, T., Geurts, S. \& Pulkkinen, L. E. A. (2006). Types of work-family interface: Well-being correlates of negative and positive spillover between work and family. Scandinavian Journal of Psychology, 47(2), 149-162.

Lu, J., Tjosvold, D., Shi, K. \& Wang, B. (2012). Developing work-family balance through conflict management. Asian Journal of Social Psychology, 15(2), 77-88.

Marks, S. (1977). Multiple roles and role strain: Some notes on human energy, time, and commitment. American Sociological Review, 42, 921-936

McNall, L. A., Nicklin, J. M. \& Masuda, A. D. (2010). A meta-analytic review of the consequences associated with work-family enrichment. Journal of Business and Psychology, 25(3), 381-396.

Michel, J. S., Kotrba, L. M., Mitchelson, J. K., Clark, M. A. \& Baltes, B. B. (2011). Antecedents of work-family conflict: A meta-analytic review. Journal of Organizational Behavior, 32(5), 689-725.

Ozbilgin, M. F., Beauregard, T. A., Tatli, A. \& Bell, M. P. (2011). Work-Life, Diversity and Intersectionality: A Critical Review and Research Agenda. International Journal of Management Reviews, 13(2), 177 198.

Panatik, S. A. B. (2010). Impact of work design on psychological work reactions and job performance among technical workers: A longitudinal study in Malaysia (Doctor of Philosophy), University of Waikato, Hamilton, New Zealand.

Proost, K., de Witte, H., de Witte, K. \& Schreurs, B. (2010). Work-family conflict and facilitation: The combined influence of the job demand-control model and achievement striving. European Journal of Work and Organizational Psychology, 19(5), 615-628.

Rothbard, N. P. (2001). Enriching or Depleting? The Dynamics of Engagement in Work and Family Roles. Administrative Science Quarterly, 46(4), 655-684.

Sieber, S. D. (1974). Toward a Theory of Role Accumulation. American Sociological Review, 39(4), 567 578.

Seery, B. L., Corrigall, E. A. \& Harpel, T. (2008). Job-Related Emotional Labor and Its Relationship to WorkFamily Conflict and Facilitation. Journal of Family and Economic Issues, 29(3), 461-477.

Shaffer, M. A., Joplin, J. R. W. \& Hsu, Y. S. (2011). Expanding the boundaries of work-family research: A review and agenda for future research. International Journal of Cross Cultural Management, 11(2), 221-268.

Siu, O. L., Lu, J. F., Brough, P., Lu, C. Q., Bakker, A. B., Kalliath, T. \& Shi, K. (2010). Role resources and workfamily enrichment: The role of work engagement. Journal of Vocational Behavior, 77 (3), 470-480.

Swee-Fung, N. \& Ahmad, A. (2012). Work-Family Enrichment: It's Mediating Role in the Relationships between Dispositional Factors and Job Satisfaction. International Journal of Academic Research in Business and Social Sciences, 2(11), 73-88.

Thompson, C. A. \& Prottas, D. J. (2006). Relationships Among Organizational Family Support, Job Autonomy, Perceived Control, and Employee Well-Being. Journal of Occupational Health Psychology, 11(1), 100-118.

Voydanoff, P. (2004). The Effects of Work Demands and Resources on Work-to-Family Conflict and Facilitation. Journal of Marriage and Family, 66(2), 398-412.

Voydanoff, P. (2005). The Effects of Community Demands, Resources, and Strategies on the Nature and Consequences of the Work-Family Interface: An Agenda for Future Research. Family Relations, 54(5), 583-595.

Wan-Rashid, W. E., Nordin, M. S., Omar, A. \& Ismail, I. (2011). Self-Esteem, Work-Family Enrichment and Life Satisfaction among Married Nurses in Health Care Service. International Journal of Trade, Economics and Fiance, 2(5), 424-429

Wayne, J. H., Randel, A. E. \& Stevens, J. (2006). The role of identity and work-family support in workfamily enrichment and its work-related consequences. Journal of Vocational Behavior, 69(3), 445461. 
Wayne, J. H., Grzywacz, J. G., Carlson, D. S. \& Kacmar, K. M. (2007). Work-family facilitation: A theoretical explanation and model of primary antecedents and consequences. Human Resource Management Review, 17(1), 63-76.

Zimmerman, K. L. \& Hammer, L. B. (2010). Work-Family Positive Spillover Contemporary Occupational Health Psychology (272-295): Wiley-Blackwell. 